\title{
Properties of Board Manufactured from Sawdust, Ricehusk and Charcoal ${ }^{1}{ }^{1}$ 踝
}

\author{
Jung-Woo HWANG ${ }^{2}$ • Seung-Won $\mathrm{OH}{ }^{2, \dagger}$
}

\begin{abstract}
In this study, the environmentally friendly material charcoal was added to ricehusk, an agricultural by-product, and sawdust, which emerges during the sawing process, to produce board by mixing ratio and concentration levels of ricehusk and charcoal; it then investigated its physical properties for development purposes and achieved the following results. The water absorption and thickness swelling of the compounded board produced per adding ratio of ricehusk and charcoal showed a gradually decreasing tendency along with the increase in adding ratio of the charcoal, and as the density of the compounded board increased, the water absorption decreased, while the thickness swelling increased. The internal bond strength of the compounded board had indicated its highest value of $0.49 \mathrm{~N} / \mathrm{mm}^{2}$ at the density of $0.7 \mathrm{~g} / \mathrm{cm}^{3}$. This satisfied the quality standard for KSF 3104 Particleboard. The internal bond strength of the compounded board manufactured per adding ratio of ricehusk and charcoal showed a steady decrease with the decrease in the adding ratio of ricehusk, and an increase in the addingratio of the charcoal. Also, in cases when the ratio of the ricehusk and charcoal by KSF 3104 quality standard were 35:5 and 30:10, it satisfied the quality standard of 15.0-type, whereas it satisfied the 13.0-type quality standard if the ratios were 25:15 and 20:20. It showed a tendency of increasing hardness of the compounded board with the increase in density, and decreasing hardness with the increase in the adding ratio of the charcoal.
\end{abstract}

Keywords: ricehusk, charcoal, water absorption, internal bond strength, brinell hardness

\section{INTRODUCTION}

Due to an increase in the interest in wood as an environmentally friendly construction material as well as in wooden materials, research development is being actively carried out on handling increasing wood and wooden material consumption, along with new wooden compound materials based on composition between daily waste materials, agricultural waste materials, etc. and wooden materials for the purposes of achieving a stable supply of wooden raw materials as well as developing a replacement raw material for insufficient wooden resources (Kim et al., 2001). Although the sawdust used in this study, which is a by-product in the sawing process, is produced in large amounts, due to its properties which require a large amount of resin, as well as thermo compression time which lengthens during manufacturing of boards, only a small quantity of sawdust had been used to achieve the smoothness and surface hardness of Particleboard. Also, despite the fact that the boards which utilized ricehusk, an agricultural by-product, had many difficulties in commercialization due

\footnotetext{
${ }^{1}$ Date Received November 4, 2019, Date Accepted December 27, 2019

2 Department of Wood Science \& Technology, Jeonbuk National University, Jeonju 54896, Republic of Korea

† Corresponding author: Seung-Won OH (e-mail: ohsw@jbnu.ac.kr, ORCID: 0000-0002-6601-9789)
} 
to the properties of the material, research had progressed in various ways (Oh et al., 2005; Oh et al., 2010; Oh, 2014). On the other hand, wooden raw materials are being gradually transformed from thoseoriginally manufactured only for wooden materials into compounded environmentally friendly materials which include functionality. A variety of research and development in particular is making progress regarding environmentally friendly materials which take into consideration their durability and functionalities (Park et al., 2013; Park et al., 2012; Hwang and Oh, 2017). Charcoal is the most easily accessible environmentally friendly material, and its usable field is being widened as further new use methods are being developed after identifying numerous features such as air and water purification, far-infrared radiation release, electromagnetic wave shielding, etc. Also, with the increase of interest in health, products which utilize charcoal have been produced in large quantity such that the use of charcoal has shown a noticeable recent increase. As such, charcoal is being newly recognized as an environmentally friendly raw material, and shows large utilization.

Choi et al. (2000) manufactured boards which utilized waste wood materials and charcoal and measured the material properties, and confirmed the result that its strength properties were relatively lower than existing boards but due to the low preservability and heat conductivity of strawberries, and checked its use potential as an ecological material, whereas Lee et al (2004, 2005) manufactured boards in various conditions by using fine charcoal, measured their material properties and confirmed their performance, and confirmed the release amount of far-infrared radiation atthe same level with fine charcoal, and an extraordinary adhesiveness of ethylene gas. Lee et al. (2006) confirmed the formaldehyde radiation reduction effect of boards made of black coal manufactured by carbonizing daily waste. Also, Seo \& Lee (2010) manufactured black coal boards by using biologically and environmentally friendly natural plasmatic concentrated additive, and confirmed that it could be utilized as a residential environmental material for indoor air quality management. Also, Park et al. (2012, 2013) used green tea, charcoal and wooden fabric to manufacture the compounded boards in various conditions andmeasure their material properties, and carried out research relevant to material development as an environmentally friendly material. Hwang \& Oh (2017) investigated the material properties of boards manufactured using rice husk and charcoal, whereas Kim (2017) had manufactured boards by using ricehusk and charcoal to develop insulating materials for structural purposes.

This study manufactured board per mixing ratio and density of ricehusk and charcoal by adding charcoal, an environmentally friendly raw material,to ricehusk, an agricultural by-product, and sawdust which emerges during the sawing process, as a part of functional development, measured its physical properties and reviewed its usability.

\section{MATERIALS and METHODS}

\subsection{Testing materials}

\subsubsection{Sawdust}

The sawdust which emerges in the sawing process of thinned logs of Larix kaemferi C was used by purchasefrom a market sawmill, and for evenness of the sample during the manufacture of the board, particle size was selected as 18 mesh by using a sorter (Shinchang, vibrator), while the water content percentage was adjusted to less than $6 \%$.

\subsubsection{Ricehusk}

The ricehusk was purchased from a market rice mill, dried in the shade, and ground with a grinder (Hanshin, $\mathrm{J}-\mathrm{NCM}$ ) in order to increase coherence during the manufacture of the board, while particle size was selected 
Table 1. Characterisitcs of phenol-formaldehyde resin for the test

\begin{tabular}{|c|c|}
\hline Items $\quad$ Resin types & $\begin{array}{c}\text { Powder resin } \\
\text { (novolak type) }\end{array}$ \\
\hline Solid content(\%) & 99 \\
\hline Melting point $\left({ }^{\circ} \mathrm{C}\right)$ & $80 \sim 95$ \\
\hline Specific gravity & - \\
\hline Celation time(sec.) & $80 \sim 120$ \\
\hline Plate flow(mm) & $30 \sim 35$ \\
\hline viscosity(cps) & - \\
\hline
\end{tabular}

as $-18 m e s h$, and the water content ratio was adjusted to below $6 \%$.

\subsubsection{Charcoal}

For oak charcoal, black coal with -100 mesh size was used after purchasing from Geumhanguam Co.

\subsubsection{Resin}

To manufacture boards, powder-type phenolic resin (Kolon Industry Co., KNB-100PL) was used, and the properties of the resins are indicated in Table 1.

\subsection{Test method}

\subsubsection{Board manufacturing}

To manufacture boards, powder-type phenolic resins were sufficiently combined in sawdust, ricehusk and charcoal which were evenly selected, inserted intoa stainless square mold placed on top of a hotplate of a thermo compressor (Daeyang Machinery, DYMSP001-026), adjusted for height of the upper portion of the sample in a constant manner, and underwent a thermo-pressurizing formation to produce a board with dimensionsof $260 \mathrm{~mm} \times 260 \mathrm{~mm} \times 11 \mathrm{~mm}$. For the manufacturing conditions of the board, the water content addingratio was fixed to $10 \%$, the density was fixed to $0.6 \mathrm{~g} / \mathrm{cm}^{2}$, the adding quantities of sawdust, ricehusk and charcoalwere differentiated as 50:35:5, 50:30:10, 50:25:15 and 50:20:20 to produce 4 different kinds, and the adding quantities of sawdust, ricehusk and charcoal were fixed to 50:20:20 and had densities set to $0.5,0.6$, and $0.7 \mathrm{~g} / \mathrm{cm}^{3}$ to produce 6 sheets each, for a total number of 42 sheets. The thermo compression temperature at this point was set to $170^{\circ} \mathrm{C}$, the pressure was set to $40 \mathrm{~kg}_{\mathrm{f}} / \mathrm{cm}^{2} \rightarrow 30 \mathrm{~kg}_{\mathrm{f}} / \mathrm{cm}^{2} \rightarrow 20 \mathrm{~kg} / \mathrm{cm}$ (3 phase pressurization), and the pressurization time was set to 9 minutes $\rightarrow 2$ minutes $\rightarrow 1$ minute (3 phase pressurization times). In order to maintain a constant thickness of the board in the process of the thermo pressurization, a thickness bar was used, and a Teflon plate was used to prevent attachment of the board's upper and lower surfaces to the hotplate due to its heat.

\subsection{Matter properties measurement}

\subsubsection{Water absorption rate, thickness swelling}

In order to measure the water absorption and thickness swelling, a test specimen of $50 \mathrm{~mm} \times 50 \mathrm{~mm} \times 11 \mathrm{~mm}$ was produced, on which a standard line was drawn along the middle in the direction of the width and length, and weight and dimensionswere measured. After that, the test specimen was soaked in water at $20 \pm 1^{\circ} \mathrm{C}$ for 24 hours, the remaining water was removed, and weight and dimensions were measuredagain. The water absorption (WA) and thickness swelling (TS) based on the water absorption was calculated by using the following formula $(1,2)$.

$$
W A=\frac{W_{24}-W_{0}}{W_{0}} \times 100
$$

Here, $\mathrm{W}_{24}$ refers to the weight (g) of the board test specimen 24 hours after soaking in water, and $\mathrm{W}_{0}$ to the weight (g) of the board test specimen before soaking in water.

$$
T S=\frac{T_{24}-T_{0}}{T_{0}} \times 100
$$


Here, $\mathrm{T}_{24}$ refers to the thickness (mm) of the board test specimen 24 hours after soaking in water, while $\mathrm{T}_{0}$ refers to the thickness $(\mathrm{mm})$ of the board test specimen before soaking in water.

\subsubsection{Internal bond strength}

In order to measure the internal bond strength, a test specimen of $50 \mathrm{~mm} \times 50 \mathrm{~mm} \times 11 \mathrm{~mm}$ was produced, a standard line was drawn down the middle in the directions of its width and length, and dimensions were measured. To identify the adhesive performance of the board, metal blocks were added on both sides of the test specimen with hot melt resin according to KS F 3104 regulation, tensile load was applied to the test specimen surface in a perpendicular direction, maximum load (P) when the internal bond was destroyed was measured, and internal bond strength (IB) was calculatedby using the following formula (3). In this case, the tensile load speed was set to $2 \mathrm{~mm} / \mathrm{min}$.

$$
I B=\frac{P}{b \times h}
$$

Here, IB refers to the internal bond strength $\left(\mathrm{N} / \mathrm{mm}^{2}\right)$, $\mathrm{P}$ to themaximum load when the internal bond is destroyed $(\mathrm{N})$, b to the width of the sample (mm), and $\mathrm{h}$ to the length of the sample (mm).

\subsubsection{Brinell hardness}

To measure the Brinell hardness, a test specimen of $50 \mathrm{~mm} \times 50 \mathrm{~mm} \times 11 \mathrm{~mm}$ was produced, and Durville pouring which measures the Brinell hardness by pressing in a steel ball on the board's surface was used. By using the pressing-in mark area that emerges by pressing in a steel ball with a certain radius on the board's surface at a constant pressure, the Brinell hardness was calculated by using the following formula (4).

$$
H B=\frac{2 P}{\pi D\left(D-\sqrt{D^{2}-d^{2}}\right)}
$$

Here, HB refers to Brinell hardness $\left(\mathrm{kg}_{\mathrm{f}} / \mathrm{mm}^{2}\right), \mathrm{P}$ to the load, D to the radius of the steel ball, and $\mathrm{d}$ to the diameter of the pressing-in surface.

\section{RESULTS and DISCUSSION}

\subsection{Water absorption}

The result of measuring the water absorption after soaking the board manufactured per manufacturing conditions in water at $20 \pm 1^{\circ} \mathrm{C}$ for 24 hours is shown in Fig. 1. The water absorption of the board manufactured by density by setting the addingratios of sawdust, ricehusk and charcoal at 50:20:20 showed that the resin-adding ratio at $10 \%$ was $131.19 \%$ when the density was $0.5 \mathrm{~g} / \mathrm{cm}^{2}, 96.26 \%$ when the density is $0.6 \mathrm{~g} / \mathrm{cm}^{2}$, and $82.13 \%$ when at $0.7 \mathrm{~g} / \mathrm{cm}^{2}$, indicating a
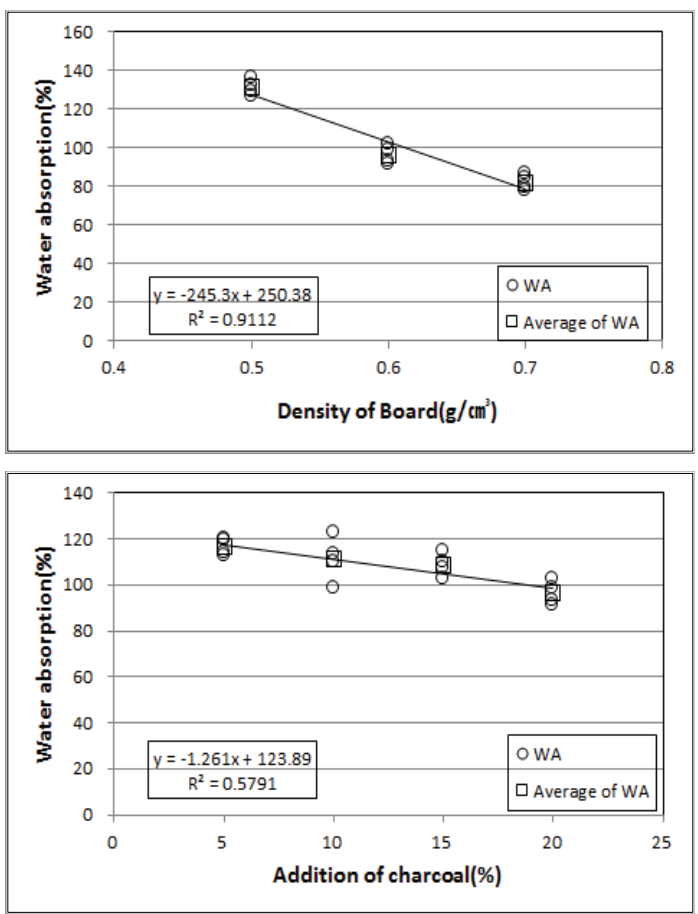

Fig. 1. Relationship between water absorption of board and density and addition of charcoal (WA: Water absorption). 
tendency of reducing water absorption with anincrease in density. The relationship between the density and water absorption was indicated as a determination coefficient $\left(\mathrm{R}^{2}\right)$ of 0.9112 through which it was shown that the density had largely affected the water absorption. The quantities of compressed sawdust, ricehusk and charcoal increased with the increase in density, and this result of reduction in water absorption is considered to be achieved as contact with water, or the movement of the water became difficult with the result of reducing porosity since the gaps between and the makeup of particles of the board were densely produced after pressurization. The coefficient of linear expansion and water absorption of the sawdust board manufactured by Lee and Yoon (1994) with MDI resins had decreased as its proportion was increased, while Oh $(2003,2013)$ had stated that the water absorption decreased with the increase in density of the sawdust board manufactured by thinned logs and the compound board manufactured fromsawdust and Mandarin peels, and Oh et al. (2012) had also reported that the water absorption of the board manufactured with giant miscanthus particles decreased with an increase in density, while the result of this research as well had showed an equivalent tendency with this result.

Also, the water absorption of the board manufactured with a density of $0.6 \mathrm{~g} / \mathrm{cm}^{3}$ by differentiating the addingratios of ricehusk and charcoal was $116.49 \%$ when the ratio of ricehusk and charcoal was 35:5, 108.71\% when it was $25: 15$, and $96.26 \%$ when it was $20: 20$, showing a tendency of gradually decreasing water absorption with the increase in the adding ratio of the charcoal.This is thought to be a reduction of water absorption since the mobility of water becomes difficult if the adding ratio of the powder-state charcoal particles increases, in which the charcoal particles will be set at a porosity between the particles of sawdust and ricehusk. However, the relationship between the adding ratio and water absorption of the ricehusk and charcoal had showed alow determination coefficient $\left(\mathrm{R}^{2}\right)$ at 0.5791; thus, it was able to be confirmed that the adding ratio of the ricehusk and charcoal had less affected the water absorption. Such a result is considered to be that, although the charcoal particles set at this porosity interfere with the mobility of water, if the adding quantity of the charcoal particles increases, because the volume to be pressurized decreases during manufacturing ofthe board, the adhesiveness would be degraded relatively despite the same density, resulting in an increase in the porosity ratio, and that the adding ratios of the ricehusk and charcoal have less of an effect on water absorption.

\subsection{Thickness swelling}

The result of measuring thickness swelling after soaking the board manufactured in water at $20 \pm 1^{\circ} \mathrm{C}$ for 24 hours is shown in Fig. 2. The thickness swelling of the board manufactured by density with adding ratios of sawdust, ricehusk and charcoal at 50:20:20 andadding ratio of resin at $10 \%$ was shown as $5.54 \%$ with density of $0.5 \mathrm{~g} / \mathrm{cm}^{3}, 7.95 \%$ with density of $0.6 \mathrm{~g} / \mathrm{cm}^{3}$, and $10.73 \%$ with density of $0.7 \mathrm{~g} / \mathrm{cm}^{3}$, showing a tendency toward increased thickness swelling with an increase in density. The relationship between the density and thickness swelling had the determination coefficient value $\left(R^{2}\right)$ of 0.7399 in which the density had largely affected the thickness swelling. Generally, in case of a board manufactured with the same resin adding ratio, it is known that as the proportion of the board increases, the dimensional stability will decrease (Sun et al., 1994). This is decided to be an effect caused by an increased quantity of particles able to expand while absorbing water after manufacturing the board due to an increase in quantities of pressed sawdust and ricehusk during the manufacturing process, althoughwater absorption increased with the increase in its density. Also, this result is considered to be combined with the properties 

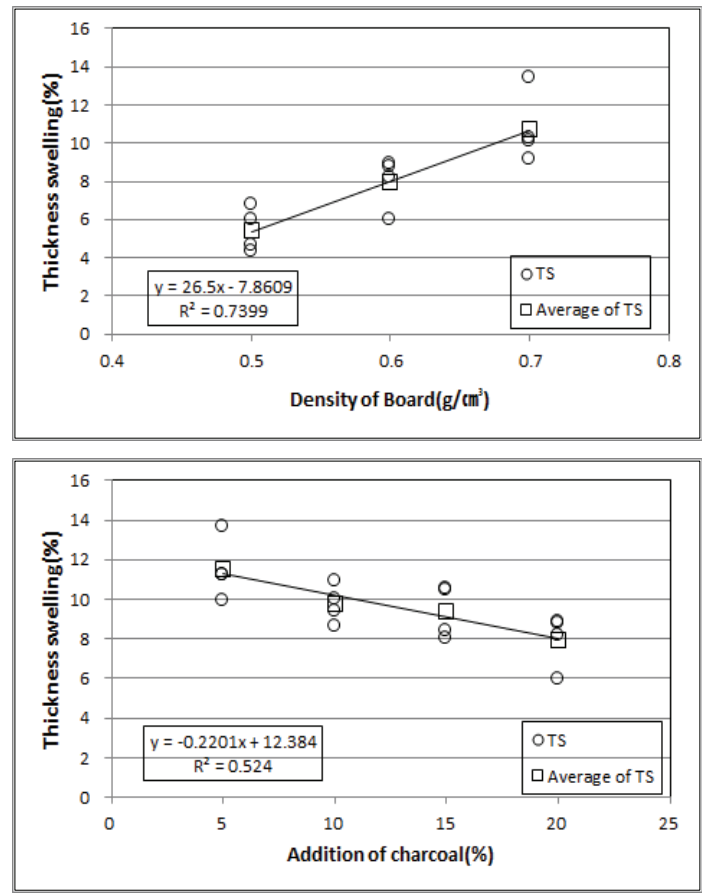

Fig. 2. Relationship between thickness swelling of board and density and addition of charcoal (TS: Thickness swelling).

of the press-formed particles that tend to revert to the condition before its formation due to the water absorption. Thus, the thickness swelling is considered to be more affected by the density than water. This result had satisfied the quality standard of KSF 3104 Particleboard. Oh $(2003,2013)$ had stated that as the densities of the sawdust board manufactured with thinned logs and the compounded board manufactured using sawdust and Mandarin peels increase, the thickness swelling increases; and Piao (2004) had reported that as the density of the compounded board manufactured using the sawdust and ricehusk increases, the thickness swelling increases steadily.

On the other hand, the thickness swelling of the board manufactured with a density of $0.6 \mathrm{~g} / \mathrm{cm}^{3}$ by setting the adding ratio of sawdust to $50 \%$ and differentiating the adding ratios of ricehusk and charcoal was shown as
$11.49 \%$ when the ratio of ricehusk and charcoal was $35: 5$, $9.73 \%$ for $30: 10,9.36 \%$ for $25: 15$, and $7.95 \%$ for 20:20, showing a tendency toward asteady decrease in thickness swelling as the adding ratio of ricehusk decreases and that of charcoal increases. This result had satisfied the quality standard of KSF 3104 Particleboard. Generally, as carbide goes through the carbonating process, hydrophilic groups such as hydrogen, oxygen, etc. change to hydrophobic groups, and the chance of forming secondary combinations with water decreases (Park et al., 2007). Thus, if the adding ratio of charcoal increases, being a carbide, the adding quantity of ricehusk particles which could swell when absorbing water decreases. It is considered that with this result the thickness swelling had decreased, leading to an increase in dimensional stability. However, the relationship between the adding ratios of sawdust, charcoal and thickness swelling showed a low determination coefficient $\left(\mathrm{R}^{2}\right)$ at 0.5240 in which the adding ratios of ricehusk and charcoal can be seen as affecting the thickness swellingless. In order to confirm the precise effect of charcoal, it is considered to be necessary to carry out tests by further increasing the adding ratio of the charcoal.

\subsection{Internal bond strength}

The result of measuring the internal bond strength based on the density of manufactured board, adding ratios of ricehusk and charcoal is shown in Fig. 3. The internal bond strength of board manufactured per density by setting the adding ratios of sawdust, ricehusk and charcoal to $50: 20: 20$, and adding ratio of resin to $10 \%$ was shown as $0.10 \mathrm{~N} / \mathrm{mm}^{2}$ with a density of $0.5 \mathrm{~g} / \mathrm{cm}^{3}$, $0.23 \mathrm{~N} / \mathrm{mm}^{2}$ for $0.5 \mathrm{~g} / \mathrm{cm}^{3}$, and $0.49 \mathrm{~N} / \mathrm{mm}^{2}$ for $0.7 \mathrm{~g} / \mathrm{cm}^{3}$, showinga tendency of increasing internal bond strength as density increased. The relationship between the density of the board and the internal bond strength had shown a determination coefficient $\left(\mathrm{R}^{2}\right)$ of 0.7838 in 

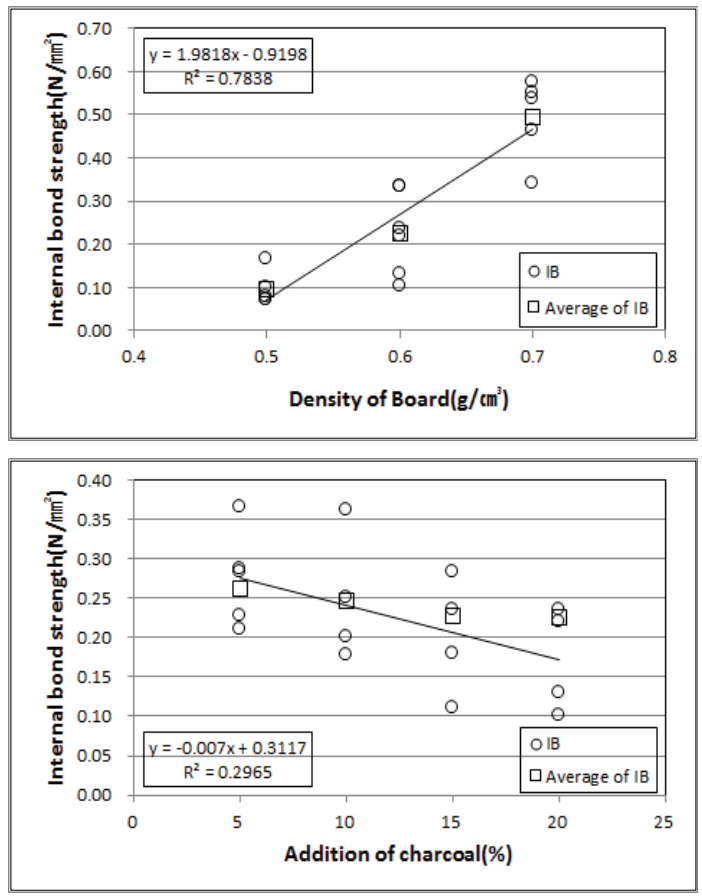

Fig. 3. Relationship between internal bond strength of board and density and addition of charcoal (IB: Internal bond strength).

which board density had been shown to largely affect the internal bond strength. Generally, board density is a crucial factor in determining the mechanical properties of board in which as the density increases, mechanical property increases. This is considered to be a result caused by increased quantities of pressed sawdust, ricehusk and charcoal with the increased density and densely producing the gaps between and organization of particles of the board after pressing to strengthen their joining force. Oh et al. (2012) had reported that the internal bond strength of board manufactured by giant miscanthus particles increased with the increase in the density, and this research as well had shown the same tendency. Also, this result had satisfied the quality standards of 8.0-type for $0.5 \mathrm{~g} / \mathrm{cm}^{3}$ density, 13.0-type for $0.6 \mathrm{~g} / \mathrm{cm}^{3}$ density, and 18.0-type for $0.7 \mathrm{~g} / \mathrm{cm}^{3}$ density with respect to the quality standard for KSF 3104 Particleboard.

On the other hand, the internal bond strength of board manufactured at $0.6 \mathrm{~g} / \mathrm{cm}^{3}$ density by differentiating the adding ratios of ricehusk, charcoal, and setting the adding ratio of sawdust at $50 \%$ was shown as $0.25 \mathrm{~N} / \mathrm{mm}^{2}$ for a $35: 5$ ratio of ricehusk and charcoal, $0.25 \mathrm{~N} / \mathrm{mm}^{2}$ for $30: 10,0.23 \mathrm{~N} / \mathrm{mm}^{2}$ for $25: 15$, and $0.23 \mathrm{~N} / \mathrm{mm}^{2}$ for $20: 20$ in which itshowed a tendency of steadily decreasing internal bond strength as the adding ratio of ricehusk decreases, and that of charcoal increases. This is decided to be a result caused by degradation of internal bond strength with reduced pressed quantity during the manufacturing process if the adding ratio of ricehusk in particle-state becomes less than that of charcoal in a powder state. Also, Park et al. (2007) had reported in matter property measurementsfor particleboard manufactured with waste wood carbide that the internal bond strength had decreased with the increase in the adding quantity of the carbide. This had shown a similar tendencywith a result stating that because the strength of the carbide itself is weaker than the strength of theparticles, it had directly impacted the internal bond strength. However, the relationship between the adding ratios of ricehusk, charcoal and internal bond strength had shown adetermination coefficient $\left(\mathrm{R}^{2}\right)$ of 0.2965 in which the adding ratios of ricehusk and charcoal had less of an effect on the internal bond strength. It is considered to be necessary to carry out additional tests with various adding ratios since the adding ratio of charcoal was inadequate. Also, this result had satisfied the quality standards of 15.0-type for 35:5 and 30:10 ratios of ricehusk and charcoal, and 13.0-type for 25:15 and 20:20 ratios with respect to the quality standards for KSF 3104 Particleboard.

\subsection{Brinell hardness}

The result of measuring the Brinell hardness based on density of manufactured board and adding ratios 

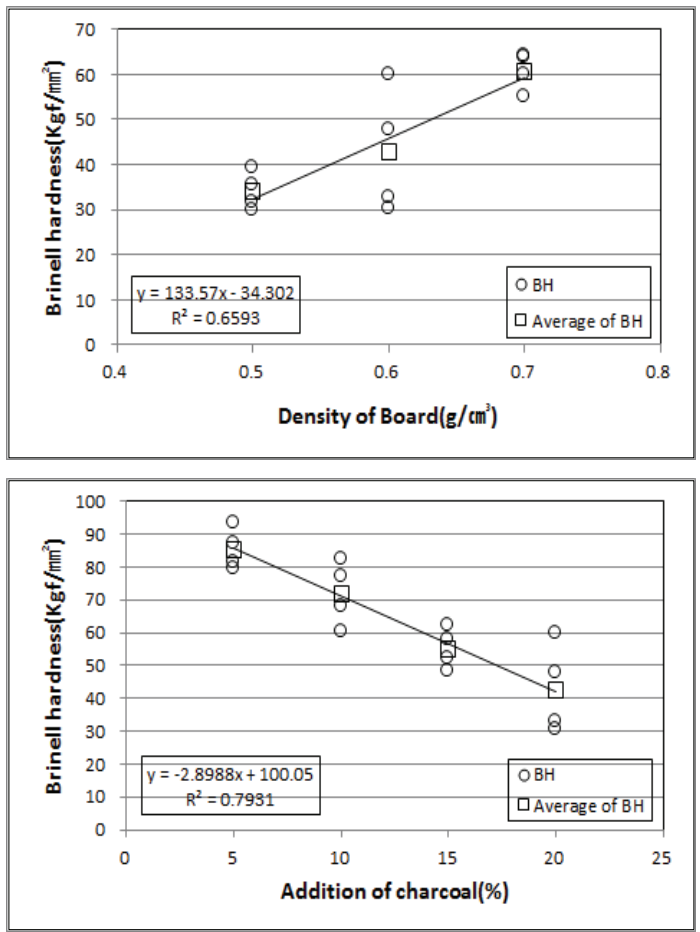

Fig. 4. Relationship between brinell hardness strength of board and density and addition of charcoal $(\mathrm{BH}$ : Brinell hardness).

of ricehusk and charcoal is shown in Fig. 4. The Brinell hardness of board manufactured per density by setting adding ratios of sawdust, ricehusk and charcoal to $50: 20: 20$, and adding ratio of resin at $10 \%$ was shown as $34.1 \mathrm{~kg} / \mathrm{mm}^{2}$ for $0.5 \mathrm{~g} / \mathrm{cm}^{3}$ density, $42.7 \mathrm{~kg} f / \mathrm{mm}^{2}$ for $0.6 \mathrm{~g} / \mathrm{cm}^{3}$, and $60.8 \mathrm{~kg} / \mathrm{mm}^{2}$ for $0.7 \mathrm{~g} / \mathrm{cm}^{3}$ which showed a tendency of increasing Brinell hardness with the increase in density. Also, the relationship between the board density and Brinell hardness had shown a determination coefficient $\left(\mathrm{R}^{2}\right)$ of 0.6593 , which showed that the density of board affects the Brinell hardness. It had indicated the same result with the research stating that generally, the Brinell hardness of wood increases proportionally with weight (Lee et al., 2008). This is a result caused by increased quantities of pressed sawdust, ricehusk and charcoal as density increases in manufacturing of the board, and strengthening the joining force by producing gaps between and an organization of the particles of the board after pressing. Oh (2003) had reported that Brinell hardness increases with the increase in density of sawdust board manufactured by using thinned logs, while Oh and Park (2009) had reported that Brinell hardness increases with the increase in density of board manufactured by using wooden parts of paper mulberry. This result had shown the same tendency with the abovementioned reports.

Also, the Brinell hardness of board manufactured with $0.6 \mathrm{~g} / \mathrm{cm}^{3}$ density by setting the adding ratio of sawdust as $50 \%$, differentiating the adding ratios of ricehusk and charcoal was shown as $85.4 \mathrm{~kg}_{\mathrm{f}} / \mathrm{mm}^{2}$ for 35.5 ratio of ricehusk and charcoal, $72.0 \mathrm{~kg}_{\mathrm{f}} / \mathrm{mm}^{2}$ for $30: 10,55.2 \mathrm{~kg}_{\mathrm{f}} / \mathrm{mm}^{2}$ for $25: 15$, and $42.7 \mathrm{~kg}_{\mathrm{f}} / \mathrm{mm}^{2}$ for 20:20 which showed a tendency of decreasing Brinell hardness with the decrease in adding ratio of ricehusk, and an increase in the adding ratio of charcoal. The relationship between the adding ratios of ricehusk, charcoal and Brinell hardness had shown a determination coefficient $\left(\mathrm{R}^{2}\right)$ of 0.7931 in which the adding ratios were indicated as affecting the Brinell hardness. Same with the internal bond strength, this is considered to be a result of degrading internal bond strength with decreased amount of pressed quantity during the manufacturing process if the adding ratio of ricehusk becomes less than that of charcoal.

\section{CONCLUSION}

This study had added the environmentally friendly material charcoal to ricehusk, an agricultural by-product, and sawdust which emerges during the sawing process to produce board per mixing ratio and concentration level of ricehusk and charcoal, investigated its physical properties for usage development purposes and achieved the following result.

It was able to be confirmed that as the density of 
board increased, the particles became more densely integrated. It was also possible to confirm that as the adding ratio of charcoal particles increases, the surface color darkens, and a greater amount of charcoal particles locate in the pores and particle surface.

The water absorption and thickness swelling of the compounded board produced per adding ratios of ricehusk and charcoal had showed the tendency to gradually decrease with the increase in adding ratio of the charcoal, and as the density of the compounded board increased, the water absorption decreased, while the thickness swelling increased.

The internal bond strength of the compounded board had indicated a highest value of $0.49 \mathrm{~N} / \mathrm{mm}^{2}$ at the density of $0.7 \mathrm{~g} / \mathrm{cm}^{3}$. It had showed a tendency toward increasing internal bond strength with the increase in density, and satisfied the quality standard of 8.0-type for $0.5 \mathrm{~g} / \mathrm{cm}^{3}$ density, 13.0-type for $0.6 \mathrm{~g} / \mathrm{cm}^{3}$, 18.0-type for $0.7 \mathrm{~g} / \mathrm{cm}^{3}$ with respect to the quality standard for KSF 3104 Particleboard. The internal bond strength of the compounded board manufactured per adding ratio of ricehusk and charcoal had showed a maximum value of $0.26 \mathrm{~N} / \mathrm{mm}^{2}$ for an adding ratio of ricehusk and charcoal of 35:5, and showed a steady decrease with the decrease in the adding ratio of the ricehusk, and an increase in the adding ratio of the charcoal. Also, in cases in which the ratio of the ricehusk andcharcoal in KSF 3104 quality standard were 35:5 and 30:10, it satisfied the quality standard of 15.0-type; whereas it satisfied the 13.0-type quality standard if the ratios were 25:15 and 20:20.

It showed a tendency of increasing hardness of the compounded board with anincrease in density, and decreasing the hardness with the increase in the adding ratio of the charcoal.

\section{REFERENCES}

Chio, Y.S., Kwon. G.J., Hwang, W.J., Han, T.H., Kwon,
J.H., Kim, N.H. 2000. New Utilization of Boards Manufactured with Wastewood and Charcoal. Journal of the Korean Society of Furniture Design and Technology 11(2): 67-72.

Hwang, J.W., Oh, S.W. 2017. Physical and mechanical properties of board made from carbonized rice husk. Journal of the Korean Wood Science and Technology 45(1): 62-71.

Kang, C.W., Kim, N.H., Kim, B.R., Kim, Y.S., Byeon, H.S., So, W.T., Yeo, H.M., Oh, S.W., Lee, W.H., Lee, H.H. 2008. New wood Physics and mechanics. hyangmunsa. 297-299.

Kim, I.B., Kim, Y.G. 2001. Recycling evaluation of rice-hull and sawdust using carborization. Journal of korean Society of environmental Administration 7(3): 439-443.

KS F 3104. 2006. Particleboard. Korean Standards Association.

Kim, G.C. 2017. A study on the strength properties of board using the carbonized rice husks to develop a structural insulation. Journal of the Korean Wood Science and Technology 45(5): 511-518.

Lee, H.H., Cho, Y.M., Park, H.S. 2004. Effect of overlaid white charcoal board on the ethylene gas adsorption and preservation life of strawberry. Journal of the Korean Wood Science and Technology 32(5): 86-92.

Lee, H.H., Cho, Y.M., Park, H.S. 2005. Manugacture and preperties of white charcoal board in relation with final mat moisture content and charcoal particle size. Journal of the Korean Wood Science and Technology 33(3): 22-29.

Lee, H.H., Seo, I.S., Park, H.S. 2006. The scavenging effect of formaldehyde release made from charcoal of waste wood. Proceedings of the Korean Society of Wood Science and Technology annual meeting. pp. 208-209.

Lee, P.W., Yoon, H.U. 1994. The properties of sawdust board in using MDI (Methylene diphenyldiiso- 
cyanate) resin( I ) - On the specific gravity, resin additive content and mat moisture content -. Journal of the Korea Furniture Socieety 5: 51-61.

Oh, S.W. 2003. Physical and mechanical properties of sawdust board made of thinning logs( II )-The effect of density and additive quentity of powder phenolic resin. Journal of the Korean Wood Science and Technology 31(3): 17-23.

Oh, S.W. 2013. Manufacturing and physical properties of composite board with sawdust and orange peels. Journal of the Korean Wood Science and Technology 41(6): 528-534.

Oh, S.W. 2014. Prooerties of sawdust-rice husk mixed ceramic according to the rice husk mixing ratios. Journal of the Korean Wood Science and Technology 42(4): 420-427.

Oh, S.W., Park, H.J. 2010. A change in surface temperature of ceramics made from board mixed with sawdust and rice husk -Effect of resin impregnation rate and carbonization temperature-. Journal of the Korean Wood Science and Technology 38(1): 43-48.

Oh, S.W., Park, H.J., Hwang, J.W. 2012. Charactistics of board made from miscanthus sinensis var. purpuracsens particles. Journal of Agriculture \& Life Science 46(2): 43-48

Oh, S.W., Park, S.C. 2009. Properties of boards prepared from woody of Broussonetia Kazinoki Sieb. Journal of the Korean Wood Science and Technology 37(3): 216-221.

Oh, S.W., Piao, J.J., Jeong, I.S. 2005. Properties of ceramics from a board mixed with sawdust and rice husk -Effect of resin impregnation rate and carbonization temperature-. Journal of the Korean Wood Science and Technology 33(3): 30-37. Park, H.M., Lee, S.K., Seok, J.H., Choi, N.K., Kwon, C.B., Heo, H.S., Byeon, H.S., Yang, J.K., Kim, J.C. 2012. Effect of green tea and sawdust contents on dynamic modulus of elasticity of hybrid boards and prediction of static bending strength performances. Journal of agriculture \& life science 46(2): 9-17

Park, H.M., Heo, H.S., Sung, E.J., Nam, K.H., Lim, J.S. 2013. Effect of the kind and content of raw materials on mechanical performances of hybrid composite boards composed of green tea, charcoals and wood fiber. Journal of the Korean Wood Science and Technology 41(1): 64-76.

Park, S.B., Lee, S.M., Park, J.Y., Kang, E.C. 2007. Properties and formaldehyde emission of particleboard fabricated with waste wood charcoal. Journal of the Korean Society of Furniture Design and Technology 18(3): 205-210.

Piao, J.J. 2004. Physical and mechanical properties of ceramics from a board mixed with sawdust and rice husk. chonbuk national university master's thesis

Seo, I.S., Lee, H.H. 2010. Properties of Black Charcoal Board Manufactured from Domestic Wood Waste by Using Serum Protein Adhesive. Journal of agricultural science 37(2): 267-270.

Sun, B.C.H., Hawke, R.N., Gale, M.R. 1994. Effect of polyisocyanate level on physical properties of wood fiber composite materials. Forest Products Journal 44(4): 53-58. 


\title{
APPENDIX
}

\author{
(Korean Version)
}

\section{톱밥과 왕겨 및 숯을 이용하여 제조한 보드의 성질}

초록 : 본 연구에서는 농업부산물인 왕겨와 제재과정에서 발생되는 톱밥에 환경 친화적인 소재인 숯을 첨가하여 왕겨와 숯의 혼합비율 및 밀도별로 보드를 제조한 후 용도개발을 위하여 물리적 성질을 조사하여 다음과 같은 결과를 얻었다. 왕겨 및 숯의 첨가율 별로 제조된 혼합보드의 수분흡수율과 두께팽윤율은 숯의 첨가율이 증가할수록 완만하게 감소하는 경향을 나타내었고, 또한 혼합보드의 밀도가 증가할수록 수분흡수율은 감소하고 두께팽윤율은 증가하는 경향을 나타냈다. 혼합보드의 박리강도는 밀도가 $0.7 \mathrm{~g} / \mathrm{cm}^{3}$ 일 때 $0.49 \mathrm{~N} / \mathrm{mm}^{2}$ 로 가장 높은 수치를 나타내었다. KSF 3104 파티클 보드의 품질기준을 만족시켰다. 왕겨 및 숯의 첨가율별로 제조된 혼합보드의 박리강도는 왕겨의 첨가율이 감소하고 숯의 첨가율이 증가할수록 박리강도가 완만하게 감소하는 경향을 나타냈다. 또한 KSF 3104 파티클 보드의 품질기준 왕겨와 숯의 비율이 35:5와 30:10일 때는 15.0형, 25:15와 20:20일 때 13.0형의 품질기준을 만족시켰다. 혼합보드의 밀도가 증가할수록 경도가 증가하는 경향을 나타냈고, 왕겨의 첨가율이 감소하고 숯의 첨가율이 증가할수록 경도는 감소하는 경향을 나타냈다.

\section{1. 서 론}

친환경 건축재료인 목재와 목질재료에 대한 관심이 증대되고 있어 목재와 목질재료의 소비량이 증대하는 상황에 대처하고, 목질원료의 안정적 수급과 부족한 목재자원의 대체원료 개발의 차원에서 일상생활 폐기물, 농산물 폐기물 등과 목질재료와의 복합화에 의한 새로운 목질복합재료에 대한 연구개발이 활발해지고 있다(Kim et al., 2001). 본 연구에서 사용한 재료인 제재 부산물인 톱밥은 많은 양이 생산되고 있음에도 톱밥의 특성상 보드 제조시 다량의 수지가 필요하며 열압시간이 길어지기 때문에 소량의 톱밥만 파티클보드의 평활성과 표면경도를 얻기 위해 사용되어 왔다. 또한 농업부산물인 왕겨를 이용한 보드가 재료의 특성상 실용화에 많은 어려움이 있음에도 불구하고 다양한 방법으로 연구가 진행되어 왔다(Oh et al., 2005; Oh et al., 2010; Oh, 2014). 한편, 목질재료는 기존의 목재소재로만 제조되던 것이 점차 기능성이 포함된 재료가 혼합된 친환경 재료로 변화하고 있다. 특히, 내구성과 기능성을 고려한 다양한 친환경재료의 연구와 개발이 이루어지고 있다(Park et al., 2013; Park et al., 2012; Hwang and Oh, 2017). 숯은 가장 쉽게 접할 수 있는 친환경 재료이며 공기 및 수질정화, 원적외선 방출, 전자파 차폐등 많은 특성이 새롭게 밝혀지면서 보다 많은 새로운 이용방법이 개발되어 그 용도가 광범위해지고 있다. 또한 건강에 대한 관심이 높아짐에 따라 숯을 이용한 상품들도 대량 생산되어 숯의 사용이 눈에 띄게 증가하고 있다. 이와 같이 숯은 최근 환경 친화적인 소재로 새롭게 인식되어 많이 이용되고 있다.

Choi et al.(2000)은 폐목재와 숯을 활용한 보드를 제조해 물성을 측정한 결과 강도적 성질이 기존에 보드에 비해 다소 낮았지만, 딸기의 보존성 및 열전도성이 낮아 생태재료로서의 이용가능성을 확인하였고, Lee et al(2004, 2005)은 백탄을 이용해 다양한 조건으로 보드를 제조한 후 물성을 측정하여 성능을 확인하였는데, 백탄과 동등한 원적외선 방사량과 뛰어난 에칠렌가스 흡착력을 보였다. Lee et al.(2006)은 생활폐잔재를 탄화시켜 제조한 흑탄으로 만든 보드의 포름알데히드 방산저감 효과를 확인하였다. 또한 Seo \& Lee(2010)는 생활목질폐잔재로부터 제조된 흑탄을 인체친화적이고 친환경적인 천연 혈장농축접착제 를 이용하여 흑탄보드를 제조하여 실내공기질 관리를 위한 주거환경재료로서 활용이 가능하다고 확인하였다. 또한 Park et al.(2012, 2013)은 녹차, 숯 및 목재섬유를 이용하여 복합보드를 여러 조건으로 제조한 후 물성을 측정하여 친환경 재료로서 소재개발에 관련된 연구를 진행하였다. Hwang \& Oh(2017)는 왕겨숯을 이용하여 제조한 보드의 물성을 조사하였고, $\mathrm{Kim}(2017)$ 은 구조용 단열재 개발을 위하여 왕겨숯을 이용하여 보드를 제조하였다.

본 연구에서는 용도개발의 일환으로 농업부산물인 왕겨와 제재과정에서 발생되는 톱밥에 환경 친화적인 소재인 숯을 첨가하 여 왕겨와 숯의 혼합비율 및 밀도별로 보드를 제조한 후 물리성질을 측정하고 이용가능성을 검토하였다. 


\section{Jung-Woo HWANG · Seung-Won OH}

\section{2. 재료 및 방법}

\section{1. 공시재료}

\subsection{1. 톱밥}

톱밥은 낙엽송(Larix kaemferi C.) 간벌재 제재시 발생된 것을 시중 제재소에서 구입하여 사용하였으며, 보드 제조시 시료의 균일함을 위하여 입자의 크기를 선별기(Shinchang, vibrator)이용하여 -18mesh로 선별하고 함수율은 $6 \%$ 이하로 조절하였다.

\subsection{2. 왕겨}

왕겨는 시중에 있는 정미소에서 구입하여 음건한 후 보드 제조시 결합력을 높이기 위하여 분쇄기(Hanshin, J-NCM)로 분쇄하여 입자크기를 - $18 m e s h$ 로 선별하고 함수율은 $6 \%$ 이하로 조절하여 사용하였다.

\subsection{3. 숯}

참나무솣은 임실의 (주금한팜에서 -100mesh 사이즈의 흑탄을 구입하여 사용하였다.

\subsection{4. 수지}

보드제조를 위하여 분말상 페놀수지(코오롱유화(주), KNB-100PL)를 사용하였고 수지의 특성은 Table 1과 같다.

\section{2. 시험방법}

\subsection{1. 보드제조}

보드를 제조하기 위하여 균일하게 선별된 톱밥과 왕겨 및 숯에 분말상 페놀수지를 충분히 혼합하였으며, 열압기(대양기계, DYMSP-001-026)의 열판위에 있는 스테인레스 정방형 몰드 속에 넣고 시료상부의 높이를 일정하게 조절한 후 열압성형 하여 $260 \mathrm{~mm} \times 260 \mathrm{~mm} \times 11 \mathrm{~mm}$ 의 보드를 제조하였다. 보드의 제조 조건은 수지첨가율을 $10 \%$ 로 고정하고 밀도를 $0.6 \mathrm{~g} / \mathrm{cm}^{3}$ 으로 고정하여, 톱밥과 왕겨 및 숯의 첨가량을 50:35:5, 50:30:10, 50:25:15, 50:20:20으로 달리하여 4종류를 제조하였고, 톱밥과 왕겨 및 숯의 첨가량을 50:20:20으로 고정하고 밀도를 $0.5,0.6,0.7 \mathrm{~g} / \mathrm{cm}^{3} 3$ 종류로 설정하여 각각 6 매씩 총 42 장를 제조하였다. 이때 열압온도는 $170^{\circ} \mathrm{C}$, 가압압력은 $40 \mathrm{~kg}_{f} / \mathrm{mm}^{2} \rightarrow 30 \mathrm{~kg}_{f} / \mathrm{cm}^{2} \rightarrow 20 \mathrm{~kg} / \mathrm{cm}$ (3단 가압), 가압시간 9 분 $\rightarrow 2$ 분 $\rightarrow 1$ 분(3단 가압시간)으로 하였다. 열압과정에서 보드의 두께를 일정하게 하기 위하여 thickness bar를 사용하였으며, 열에 의한 보드의 상 - 하면과 열판의 부착을 방지하기 위하여 테프론 판을 사용하였다.

\section{3. 물성측정}

\subsection{1. 수분흡수율, 두께팽윤율}

수분흡수율(Water absorption)과 두께팽윤율(thickness swelling)을 측정하기 위하여, $50 \mathrm{~mm} \times 50 \mathrm{~mm} \times 11 \mathrm{~mm}$ 의 시험편을 제작한 후 시험편에 폭 및 길이방향으로 중앙에 기준선을 긋고, 중량과 치수를 측정하였다. 그 후 $20 \pm 1^{\circ} \mathrm{C}$ 의 물속에 24 시간 침지한 후, 여분의 수분을 제거하고 다시 중량과 치수를 측정하였다. 수분흡수에 따른 수분흡수율(WA)과 두께팽윤율(TS)은 다음 식 $(1,2)$ 을 이용하여 계산하였다.

$$
W A=\frac{W_{24}-W_{0}}{W_{0}} \times 100
$$

여기서, $\mathrm{W}_{24}$ : 수중 침지 24시간 후의 보드 시험편의 중량 $(\mathrm{g}), \mathrm{W}_{0}$ 은 수중 침지전의 보드 시험편의 중량(g)

$$
T S=\frac{T_{24}-T_{0}}{T_{0}} \times 100
$$

여기서, $\mathrm{T}_{24}$ : 수중 침지 24 시간 후의 보드 시험편의 두께 $(\mathrm{mm}), \mathrm{T}_{0}$ 은 수중 침지전의 보드 시험편의 두께(mm)

\subsection{2. 박리강도}

박리강도(Internal bond strength)를 측정하기 위하여, $50 \mathrm{~mm} \times 50 \mathrm{~mm} \times 11 \mathrm{~mm}$ 의 시험편을 제작한 후 시험편에 폭 및 길이방향 으로 중앙에 기준선을 긋고, 치수를 측정하였다. 보드의 접착성능을 알아보기 위해 KS F 3104 규정에 따라 금속블록을 시험편 양옆에 핫 멜트 수지로 접착하고 시험편의 표면에 수직으로 인장 하중을 가하여, 박리 파괴시의 최대하중 $(\mathrm{P})$ 을 측정하여 다음 식 (3)을 이용하여 박리강도(IB)를 계산하였다. 이 경우 인장 하중 속도는 $2 \mathrm{~mm} / \mathrm{min}$ 으로 하였다. 


$$
I B=\frac{P}{b \times h}
$$

여기서, IB : 박리강도 $(\mathrm{N} / \mathrm{mm}), \mathrm{P}$ : 박리 파괴시의 최대하중 $(\mathrm{N}), \mathrm{b}$ : 시료의 나비 $(\mathrm{mm}), \mathrm{h}$ : 시료의 길이 $(\mathrm{mm})$

\subsection{3. 경도}

경도(Brinell hardness)를 측정하기 위해 $50 \mathrm{~mm} \times 50 \mathrm{~mm} \times 11 \mathrm{~mm}$ 의 시험편을 제작한 후 강구를 보드표면에 압입시켜서 경도를 측정하는 정적 압입법인 brinell 경도법을 사용하였다. 보드표면에 일정 지름의 강구를 일정 압력으로 압입하여 생긴 압입자국의 면적을 이용하여 다음 식 (4)로 구하였다.

$$
H B=\frac{2 P}{\pi D\left(D-\sqrt{D^{2}-d^{2}}\right)}
$$

여기서, $\mathrm{HB}$ : 브리넬 경도 $\left(\mathrm{kg}_{\mathrm{f}} / \mathrm{mm}^{\mathrm{n}}\right), \mathrm{P}$ : 하중, $\mathrm{D}$ : 강구의 지름, $\mathrm{d}$ : 압입면의 지름

\section{3. 결과 및 고찰}

\section{1. 수분흡수율}

제조 조건별로 제조된 보드를 $20 \pm 1{ }^{\circ} \mathrm{C}$ 의 물속에 24 시간 침지한 후 수분흡수율(water absorption)을 측정한 결과는 Fig. 1 과 같다. 톱밥과 왕겨 및 숯의 첨가율을 50:20:20, 수지첨가율을 $10 \%$ 로하여 밀도별로 제조한 보드의 수분흡수율은 밀도가 $0.5 \mathrm{~g} / \mathrm{cm}$ 일 때 $131.19 \%, 0.6 \mathrm{~g} / \mathrm{cm}^{3}$ 일 때 $96.26 \%$ 그리고 $0.7 \mathrm{~g} / \mathrm{cm}^{3}$ 일 때 $82.13 \%$ 로 밀도가 증가할수록 수분흡수율이 감소하는 경향을 나타내 었다. 밀도와 수분흡수율 사이의 관계는 결정계수의 값 $\left(\mathrm{R}^{2}\right)$ 이 0.9112 로 밀도가 수분흡수율에 큰 영향을 주는 것으로 나타났다. 이는 밀도가 높아질수록 압체되는 톱밥, 왕겨 및 숯의 양이 증가하는데, 이는 압체 후 보드의 파티클간의 간격 및 조직을 치밀하게 만들어 공극이 줄어드는 결과로 인해 수분과의 접촉이나 수분의 이동이 어려워지면서 수분흡수율이 감소하였다고 생각된다. Lee and Yoon(1994)이 MDI 수지로 제조된 톱밥보드의 선팽창율 및 물흡수율은 비중이 증가할수록 감소하였고, $\mathrm{Oh}(2003,2013)$ 는 간벌재로 제조한 톱밥보드와 톱밥과 귤박을 이용해 제조한 혼합보드의 밀도가 증가할수록 수분흡수율이 감소한다고 하였고, Oh et al.(2012)도 거대억새 파티클로 제조된 보드의 수분흡수율이 밀도가 증가할수록 감소하였다고 보고 한 바 있어 본 연구결과도 이와 일치된 경향을 나타내었다.

또한 톱밥첨가율을 $50 \%$ 로 하고, 왕겨와 숯의 첨가율을 달리하여 밀도 $0.6 \mathrm{~g} / \mathrm{cm}^{3}$ 으로 제조한 보드의 수분흡수율은 왕겨와 숯의 비율이 35:5일 때 $116.49 \%$, 30:10일 때 $111.07 \%, 25: 15$ 일 때 $108.71 \%$ 그리고 20:20일 때 96.26\%로 숯의 첨가율이 증가할수록 수분흡수율이 완만하게 감소하는 경향을 나타내었는데, 이는 분말상태의 솣가루의 첨가율이 높아지면 보드제조시 톱밥과 왕겨 파티클간의 공극에 솣가루가 위치하여 수분의 이동이 어려워 수분흡수율이 감소하였다고 생각된다. 하지만 왕겨와 숯의 첨가율과 수분흡수율 사이의 관계는 결정계수의 값 $\left(\mathrm{R}^{2}\right)$ 이 0.5791 로 낮아 왕겨와 숯의 첨가율이 수분흡수율에 주는 영향이 적은 것을 알 수 있었다. 이러한 결과는 공극에 위치한 솣가루가 수분이동을 방해하는 반면 솣가루의 첨가량이 증가하면 보드 제조시 압체할 수 있는 부피가 감소하기 때문에 상대적으로 동일 밀도라도 결합력이 저하되어 공극율이 높아져 왕겨와 솣의 첨가율이 수분흡수율에 주는 영향이 적은것으로 생각된다.

\section{2. 두께팽윤율}

제조 조건별로 제조된 보드를 $20 \pm 1^{\circ} \mathrm{C}$ 의 물속에 24 시간 침지한 후 두께팽윤율(thickness swelling)을 측정한 결과는 Fig. 2 와 같다. 톱밥과 왕겨 및 숯의 첨가율을 $50: 20: 20$, 수지첨가율을 $10 \%$ 로하여 밀도별로 제조한 보드의 두께팽윤율은 밀도가 $0.5 \mathrm{~g} / \mathrm{cm}^{3}$ 일 때 $5.54 \%, 0.6 \mathrm{~g} / \mathrm{cm}^{3}$ 일 때 $7.95 \%$ 그리고 $0.7 \mathrm{~g} / \mathrm{cm}^{3}$ 일 때 $10.73 \%$ 로 밀도가 증가할수록 두께팽윤율이 증가하는 경향을 나타내었다. 밀도와 수분흡수율 사이의 관계는 결정계수의 값 $\left(\mathrm{R}^{2}\right)$ 이 0.7399로 밀도가 두께팽윤율에 많은 영향을 주는 것으로 나타났다. 일반적으로 동일한 수지 첨가량으로 제조된 보드의 경우 보드의 비중이 증가함에 따라 치수안정성이 나쁜 것으로 알려져 있다(Sun et al., 1994). 이는 밀도가 증가할수록 수분흡수율이 증가하였지만 보드 제조시 압체하는 톱밥과 왕겨의 파티클의 양이 많아져서 적은 양은 수분이라도 보드제조 후 수분흡수시에 팽창할 수 있는 파티클의 양이 증가되어 생긴 영향으로 판단되며, 또한 압체성형된 파티클이 수분흡수에 의해 성형전의 상태로 복원하려는 성질이 복합적으로 영향을 미친 것으로 사료된다. 따라서 두께팽윤율은 수분보다는 밀도에 영향이 큰 것으로 사료된다. 이러한 결과는 KSF 3104 파티클 보드의 품질기 준을 만족시켰다. Oh(2003, 2013)는 간벌재로 제조한 톱밥보드와 톱밥과 귤박을 이용해 제조한 혼합보드의 밀도가 증가할수록 두께팽윤율이 증가한다고 하였고, Piao(2004)은 톱밥과 왕겨를 이용해 제조한 혼합보드의 밀도가 증가할수록 두께팽윤율이 
완만하게 증가한하고 보고하였다.

한편 톱밥첨가율을 $50 \%$ 로 하고, 왕겨와 숯의 첨가율을 달리하여 밀도 $0.6 \mathrm{~g} / \mathrm{cm}^{3}$ 으로 제조한 보드의 두께팽윤율은 왕겨와 숯의 비율이 35:5일 때 $11.49 \%, 30: 10$ 일 때 9.73\%, 25:15일 때 9.36\% 그리고 20:20일 때 7.95\%로 왕겨의 첨가율이 감소하고 숯의 첨가율이 증가하면 두께팽윤율이 완만하게 감소하는 경향을 나타내었다. 이러한 결과는 KSF 3104 파티클보드의 품질기준 을 만족시켰다. 일반적으로 탄화물이 탄화과정을 거치면서 수소, 산소등과 같은 친수성을 가지는 그룹들이 소수성을 가지는 그룹으로 변화하여 수분과 2차결합을 형성할수 있는 확률이 감소한다(Park et al., 2007). 따라서 탄화물인 숯의 첨가율이 증가하면 수분흡수시 팽윤할 수 있는 왕겨파티클의 첨가량이 감소하는데 이 결과로 두께팽윤율이 감소하여 치수안정성이 좋아졌다고 생각된다. 하지만 왕겨와 숯의 첨가율과 두께팽윤율 사이의 관계는 결정계수의 값 $\left(\mathrm{R}^{2}\right)$ 이 0.5240 로 낮아 왕겨와 숯의 첨가율이 두께팽윤율에 주는 영향이 적다고 볼 수 있는데, 정확한 숯의 영향을 확인하기 위해서는 숯의 첨가율을 더 높여 실험을 진행할 필요가 있다고 생각된다.

\section{3. 박리강도}

제조한 보드의 밀도와 톱밥과 왕겨 및 숯의 첨가율에 따른 박리강도(internal bond strength)를 측정한 결과는 Fig. 3과 같다. 톱밥과 왕겨 및 숯의 첨가율을 $50: 20: 20$, 수지첨가율을 $10 \%$ 로하여 밀도별로 제조한 보드의 박리강도는 밀도 $0.5 \mathrm{~g} / \mathrm{cm}^{3}$ 일 때 $0.10 \mathrm{~N} / \mathrm{mm}^{2}, 0.6 \mathrm{~g} / \mathrm{cm}^{2}$ 일 때 $0.23 \mathrm{~N} / \mathrm{mm}^{2}$ 그리고 $0.7 \mathrm{~g} / \mathrm{cm}^{3}$ 일 때 $0.49 \mathrm{~N} / \mathrm{mm}^{2}$ 로 밀도가 증가할수록 박리강도가 증가하는 경향을 나타내었다. 보드의 밀도와 박리강도 사이의 관계는 0.7838 의 결정계수 값 $\left(\mathrm{R}^{2}\right)$ 을 보여 보드의 밀도가 박리강도에 큰 영향을 나타내는 것으로 나타났다. 이는 일반적으로 보드의 역학적 성질을 결정하는데 있어서 보드의 밀도는 중요한 결정요소로서, 보드의 밀도가 증가할수록 강도적 성질이 상승하는데, 이는 밀도가 높아질수록 압체되는 톱밥, 왕겨 및 숯의 양이 증가하여 압체 후 보드의 파티클간의 간격 및 조직을 치밀하게 만들어 결합력을 강화시켜 생기는 결과로 사료된다. Oh et al.(2012)도 거대억새 파티클로 제조된 보드의 박리강도가 밀도가 증가할수록 증가하였다고 보고 하였는데, 본 연구결과도 이와 일치된 경향을 나타내었다. 또한 이러한 결과는 KSF 3104 파티클 보드의 품질기준에 대해 밀도 $0.5 \mathrm{~g} / \mathrm{cm}^{3}$ 일 때 8.0 형, $0.6 \mathrm{~g} / \mathrm{cm}^{\circ}$ 일 때 13.0 형 그리고 $0.7 \mathrm{~g} / \mathrm{cm}^{3}$ 일 때 18.0 형의 품질기준을 만족시켰다.

한편 톱밥첨가율을 $50 \%$ 로 하고, 왕겨와 숯의 첨가율을 달리하여 밀도 $0.6 \mathrm{~g} / \mathrm{cm}^{3}$ 으로 제조한 보드의 박리강도는 왕겨와 숯의 비율이 35:5일 때 $0.26 \mathrm{~N} / \mathrm{mm}^{2}, 30: 10$ 일 때 $0.25 \mathrm{~N} / \mathrm{mm}^{2}, 25: 15$ 일 때 $0.23 \mathrm{~N} / \mathrm{mm}^{2}$ 그리고 $20: 20$ 일 때 $0.23 \mathrm{~N} / \mathrm{mm}^{2}$ 으로 왕겨의 첨가율이 감소하고 숯의 첨가율이 증가할수록 박리강도가 완만하게 감소하는 경향을 나타내었다. 이는 파티클 상태의 왕겨의 첨가율이 분말상태인 숯의 첨가량보다 적어지면 보드제조시 압체량이 적어져 내부결합력을 약화시킨 결과라고 사료된다. 또한 Park et al.(2007)은 폐목재 탄화물로 제조한 파티클보드의 물성측정에서 탄화물의 첨가량이 증가할수록 박리강도가 감소하였는데, 이는 탄화물 자체의 강도가 파티클의 강도보다 약하기 때문에 내부결합력에 직접적인 영향을 미쳤다고 보고한 결과와 비슷한 경향을 나타냈다. 하지만 왕겨와 숯의 첨가율과 박리강도 사이의 관계는 결정계수 값 $\left(\mathrm{R}^{2}\right)$ 을 0.2965 의 값을 보여 왕겨와 숯의 첨가율이 박리강도에 주는 영향은 적은 것으로 나타났는데, 이는 숯의 첨가량이 미비하여 다양한 첨가율 비율로 추가실험이 필요할 것이라고 생각된다. 또한 이러한 결과는 KSF 3104 파티클 보드의 품질기준에 대해 왕겨와 숯의 비율이 35:5와 30:10일 때는 15.0형, 25:15와 20:20일 때 13.0형의 품질기준을 만족시켰다.

\section{4. 경도}

제조한 보드의 밀도와 톱밥과 왕겨 및 숯의 첨가율에 따른 경도(brinell hardness)를 측정한 결과는 Fig. 4 와 같다. 톱밥과 왕겨 및 숯의 첨가율을 $50: 20: 20$, 수지첨가율을 $10 \%$ 로하여 밀도별로 제조한 보드의 경도는 밀도가 $0.5 \mathrm{~g} / \mathrm{cm}^{3}$ 일 때 $34.1 \mathrm{~kg}_{\mathrm{f}} / \mathrm{mm}^{2}$, $0.6 \mathrm{~g} / \mathrm{cm}^{3}$ 일 때 $42.7 \mathrm{~kg}_{\mathrm{f}} / \mathrm{mm}^{2}$ 그리고 $0.7 \mathrm{~g} / \mathrm{cm}^{\prime}$ 일 때 $60.8 \mathrm{~kg}_{\mathrm{f}} / \mathrm{mm}^{2}$ 로 밀도가 증가할수록 경도가 증가하는 경향을 보였다. 또한 보드의 밀도와 경도 사이의 관계는 결정계수 값 $\left(\mathrm{R}^{2}\right)$ 을 0.6593 의 값을 보여 보드의 밀도가 보드의 경도에 영향을 주는 것으로 나타났다. 일반적으로 목재의 경도는 비중에 비례하여 증가하는 경향이 있다는 연구(Lee et al., 2008)와 같은 결과를 보였다. 이는 밀도가 증가할수록 보드제조시에 압체되는 톱밥, 왕겨 및 숯의 양이 증가하는데 이는 압체 후 보드의 파티클간의 간격 및 조직을 치밀하게 만들어 결합력을 강화시켜 생기는 결과이다. $\mathrm{Oh}(2003)$ 는 간벌재를 이용해 제조한 톱밥보드의 밀도가 증가할수록 경도가 증가한다고 보고하였고, Oh and Park(2009)은 닥나무 목질부를 이용해 보드를 제조시할 시 보드의 밀도가 증가할수록 경도가 증가한다고 보고한 내용과 같은 경향을 나타냈다.

또한 톱밥첨가율을 $50 \%$ 로 하고, 왕겨와 숯의 첨가율을 달리하여 밀도 $0.6 \mathrm{~g} / \mathrm{cm}^{3}$ 으로 제조한 보드의 경도는 왕겨와 숯의 비율이 $35: 5$ 일 때 $85.4 \mathrm{~kg}_{\mathrm{f}} / \mathrm{mm}^{2}, 30: 10$ 일 때 $72.0 \mathrm{~kg}_{\mathrm{f}} / \mathrm{mm}^{2}, 25: 15$ 일 때 $55.2 \mathrm{~kg}_{\mathrm{f}} / \mathrm{mm}^{2}$ 그리고 $20: 20$ 일 때 $42.7 \mathrm{~kg}_{\mathrm{f}} / \mathrm{mm}^{2}$ 으로 왕겨의 첨가율이 감소하 
고 숯의 첨가율이 증가할수록 경도가 감소하는 경향을 나타내었고, 왕겨와 숯의 첨가율과 경도 사이의 관계는 결정계수 값 $\left(\mathrm{R}^{2}\right)$ 을 0.7931의 값을 가져 첨가율이 보드의 경도에 영향을 주는 것으로 나타났다. 이는 박리강도와 마찬가지로 파티클 상태의 왕겨의 첨가율이 분말상태인 숯의 첨가량보다 적어지면 보드제조시의 압체량이 적어져 내부결합력을 약화시킨 결과라고 사료된다.

\section{4. 결 론}

본 연구에서는 농업부산물인 왕겨와 제재과정에서 발생되는 톱밥에 환경 친화적인 소재인 솣을 첨가하여 왕겨와 숯의 혼합비 율 및 밀도별로 보드를 제조한 후 용도개발을 위하여 물리적 성질을 조사하여 다음과 같은 결과를 얻었다.

보드의 밀도가 증가할수록 파티클이 좀더 촘촘하게 결합되어 있는 것을 확인할 수 있다. 솣가루의 첨가율이 증가할수록 표면의 색상이 좀 더 어두운 것을 확인할 수 있었고, 숯가루가 공극과 파티클 표면에 많이 위치하고 있는 것을 확인할 수 있다.

왕겨 및 숯의 첨가율별로 제조된 혼합보드의 수분흡수율과 두께팽윤율은 왕겨의 첨가율이 감소하고 숯의 첨가율이 증가할수 록 완만하게 감소하는 경향을 나타내었고, 또한 혼합보드의 밀도가 증가할수록 수분흡수율은 감소하고 두께팽윤율은 증가하는 경향을 나타냈다.

혼합보드의 박리강도는 밀도가 $0.7 \mathrm{~g} / \mathrm{cm}^{2}$ 일 때 $0.49 \mathrm{~N} / \mathrm{mm}^{2}$ 로 가장 높은 수치를 나타내었다. 밀도가 증가할수록 박리강도가 증가하 는 경향을 나타냈고, KSF 3104 파티클 보드의 품질기준 밀도 $0.5 \mathrm{~g} / \mathrm{cm}^{3}$ 일 때 8.0 형, $0.6 \mathrm{~g} / \mathrm{cm}^{3}$ 일 때 13.0 형 그리고 $0.7 \mathrm{~g} / \mathrm{cm}^{3}$ 일 때 18.0형의 품질기준을 만족시켰다.

왕겨 및 숯의 첨가율별로 제조된 혼합보드의 박리강도는 왕겨 및 숯의 첨가율이 35:5일 때 박리강도가 $0.26 \mathrm{~N} / \mathrm{mm}^{2}$ 로 가장 높은 수치를 나타내었고, 왕겨의 첨가율이 감소하고 숯의 첨가율이 증가할수록 박리강도가 완만하게 감소하는 경향을 나타냈다. 또한 KSF 3104 파티클 보드의 품질기준 왕겨와 숯의 비율이 35:5와 30:10일 때는 15.0형, 25:15와 20:20일 때 13.0형의 품질기준을 만족시켰다.

혼합보드의 밀도가 증가할수록 경도가 증가하는 경향을 나타냈고, 왕겨의 첨가율이 감소하고 숯의 첨가율이 증가할수록 경도는 감소하는 경향을 나타냈다. 